\title{
Guest Editor's Introduction: Newly Discovered Documents from Ancient Korea
}

In this special issue, we have included four papers that were presented at the 28th Association for Korean Studies in Europe (AKSE) Conference held in Prague, Czech Republic, in April 2017. All four papers discussed historical texts that were newly discovered after 2000, including inscribed wooden tablets (mokkan, 木簡), stele (sŏkbi, 石碑), and epitaphs (myojimyŏng, 墓誌銘).

First, Dae-Jae Park's paper discusses a new approach to examine the household register of Lelang Commandery, which was discovered in P'yŏngyang, North Korea, and first introduced to the world in 2006. The household register of Lelang Commandery is a set of wooden documents with detailed information on the number of households in each of the 25 counties in Lelang Commandery in 45 BCE. Through an examination of the characters “其戶 (kiho)," found near the end of the register, Park confirms that the households in 18 counties centered around the county town (Chosŏn county) were distinguished from the households in the seven counties of Yŏngdong (嶺東) in Lelang Commandery. Based on this trend in documentation, it is possible to presume that the seven counties of Yŏngdong were areas under the rule of both the governor of Lelang Commandery and the commandant headquarters of the East Section

* Professor, Department of Korean History, Korea University, Seoul, South Korea 


\section{(東部都尉).}

Second, Jong-Rok Lee's paper reexamines Koguryŏ's sumyoche (守墓制), a system in which certain commoners were selected to guard the royal tombs as a means of punishment and control, through "the Stele of Koguryŏ in Ji'an (集安高句麗碑, Chiban Koguryŏbi) found in China in 2012. Through the inscriptions on the stele, Lee concludes that the provision on the "prohibition of selling and purchasing people who guarded the royal tombs" not only pertained to sumyoche but that the "selling and purchasing of labor" was a common problem that emerged in the labor mobilization system. The above-mentioned provision was presumed to be a policy implemented to address the labor shortage issue, which resulted from Koguryŏ's wars with the Former Yan and Paekche around the fourth century.

Third, Dongmin Lim examines the activities of the people of Paekche after the collapse of the state by examining the epitaphs of the Ye (禰) family, discovered in Xi' an, China, in the 2010s. Lim finds that the origin and lineage of the Ye family became more Sinicized and specific over time, and confirms that it was highly likely for the descendants of the Ye family to have created records on their ancestors in order to adapt to their life in Tang China. The paper also confirms that the Ye family began to live in Paekche in the sixth century at the latest, and became used to the language and culture of Paekche as well.

Lastly, Nari Kang's paper provides a new analysis of the most recently discovered wooden tablet documents excavated from Sŏngsan Fortress in Haman, North Kyŏngsang Province. By 2016, a total of 314 wooden tablets were found at Sŏngsan Fortress in Haman, most of which were labels (hach'al) created in different regions of Silla and sent to Sŏngsan Fortress in the mid-sixth century. Through two wooden tablets, 17-No. 1 and Chajŏn-No. 221, Kang confirms that: 1) “taebŏp (代法)” was a law that stipulated a length of time for laborers per rotation, and 2) a labor mobilization system based on the unit of ch'on (village) was already established in mid-sixth century Silla.

Through these four articles and their introduction of newly discovered 
sources on ancient Korean history, we hope to stimulate further discussion and provide new interpretations on controversial historical issues. Given the paucity of sources on the ancient period, these new discoveries supply us with badly needed information and a better understanding of this period. In addition, given the interaction between the different states in the area, we believe this research will also improve our knowledge of the region as a whole. 
